\title{
Pembelajaran Dalam Jaringan (Daring) Mata Pelajaran PAI Siswa Kelas VIII SMP Qu'ran Darul Fattah Bandar Lampung Tahun Pelajaran 2020/2021
}

\author{
Langgeng Sutopo \\ STIT Darul Fattah Bandar Lampung \\ langgengsutopo@darulfattah.ac.id
}

\begin{abstract}
This research was motivated by the covid-19 pandemic which makes the world of education, especially Indonesia innovate to do Arabic language learning that is implemented online. This study aims determine the effectiveness of inline learning on Arabic language subjects that include the response of students, parents and teachers as well as the difficulties encountered in the implementation of online learning at PAI subjects. The subject in this study is the students of class VIII SMP Qur'an Darul Fattah Bandar Lampung with a total of 36 students. The research method used is descriptive qualitative, data collection techniques are carried out using interview, questionnaires and documentation. The result of the interview and questionnaire distribution was that $75 \%$ of parents agreed that online learning was not effectively applied in learning and $50 \%$ of parents are dissatisfied with online learning. $69 \%$ of students think face-to-face learning is more effective than online learning and ranges from about 50\% above who do not like changes in the implementation of learning, while teachers argue that online learning is less effective in applying Arabic language learning because students have difficulty understanding lessons. The biggest difficulty experienced by many types of respondents is the inadequate internet network.
\end{abstract}

Keywords: online learning, effectiveness, response, difficult

\begin{abstract}
ABSTRAK
Penelitian ini dilakukan adanya pandemi covid-19 yang menjadikan dunia pendidikan khususnya Indonesia berinovasi melakukan pembelajaran PAI yang dilaksanakan secara daring. Penelitian ini bertujuan untuk mengetahui efektifitas pembelajaran daring terhadap mata pelajaran PAI yang mencakup respon siswa, orang tua dan guru serta kesulitan yang dihadapi dalam pelaksanaan pembelajaran daring mata pelajaran PAI. Subjek dalam penelitian ini adalah siswa kelas VIII SMP Qur'an Darul Fattah Bandar Lampung dengan jumlah 36 siswa. Metode penelitian yang digunakan adalah deskriptif kualitatif, teknik pengambilan data yang dilakukan menggunakan wawancara, angket dan dokumentasi. Hasil dari wawancara dan pembagian angket adalah $75 \%$ orang tua setuju bahwa pembelajaran daring tidak efektif diterapkan dalam pembelajaran dan $50 \%$ orang tua tidak puas dengan pembelajaran melalui daring. Serta $69 \%$ siswa menganggap pembelajaran secara tatap muka lebih efektif dari pembelajaran daring dan berkisar sekitar 50\% ke atas yang tidak menyukai perubahan pada pelaksanaan pembelajaran, sedangkan guru berpendapat bahwa pembelajaran daring kurang efektif diterapkan pada pembelajaran PAI karena siswa sulit
\end{abstract}


memahami pelajaran. Kesulitan terbesar yang banyak dialami oleh ketiga jenis responden adalah jaringan internet yang kurang memadai.

Kata kunci: Pembelajaran daring, efektifitas, respon, kesulitan.

\section{PENDAHULUAN}

Covid-19 adalah peyakit yang menyerang pernapasan manusia (kementerian kesehatan 2020). Corona virus diseases penyakit jenis baru yang belum pernah diidentifikasi di tubuh manusia. Penyebaran Covid-19 menjadi penyebab angka kematian yang paling tinggi di berbagai dunia saat ini. Pada tanggal 30 Januari 2020 WHO telah menetapkan sebagai kedaruratan masyarakat yang meresahkan dunia.

Tentu dengan adanya Covid-19 di Indonesia membawa berbagai dampak yang negatif di segala bidang seperti ekonomi, sosial, pariwisata dan pendidikan. Untuk mengurangi penyebaran virus corona pemerintah menghentikan segala kegiatan yang berada di dalam ataupun di luar ruangan yang bersifat publik. Pada tanggal 24 maret 2020 Menteri Pendidikan dan Kebudayaan Republik Indonesia mengeluarkan Surat Edaran Nomor 4 tahun 2020 Tentang Pelaksanaan Kebijakan Pendidikan Dalam Masa Darurat Penyebaran Covid, dalam surat edaran tersebut dijelaskan bahwa proses belajar mengajar dilaksanakan di rumah melalui pembelajaran daring/jarak jauh dilaksanakan untuk memberikan pengalaman belajar yang bermakna bagi siswa. Belajar di rumah dapat difokuskan pada pendidikan kecakapan hidup antara lain mengenai pandemi Covid-19. SMP Qur'an Darul Fattah Bandar Lampung merupakan salah satu sekolah yang menerapkan pembelajaran daring.

Menurut Moore dkk dalam Sadikin (2020: 215) menyatakan pembelajaran daring merupakan pembelajaran yang menggunakan internet dengan aksebilitas, konektivitas, fleksibilitas, dan kemampuan untuk memunculkan berbagai jenis interaksi pembelajaran. Salah satu pelajaran yang terdampak Covid-19 adalah pelajaran PAI. Dalam proses pembelajaran PAI peran guru sangatlah penting. Sehingga para guru harus bisa berinovasi menciptakan metode atau media-media yang dapat mendukung terlaksananya pembelajaran PAI melalui jaringan internet. 
Penerapan pembelajaran daring tentunya memengaruhi kondisi siswa dan guru mata pelajaran PAI, walaupun pembelajaran daring dapat memberikan pengajaran yang baik, tetap saja pembelajaran daring memiliki kesulitan-kesulitan tersendiri. Oleh karena itu, dalam penelitian ini peneliti menganalisis respon dan kesulitan-kesulitan guru, siswa dan orang tua siswa dalam pembelajaran daring.

\section{METODE PENELITIAN}

Metode penelitian yang digunakan dalam penelitian ini yaitu deskriptif kualitatif. Dalam penelitian ini memanfaatkan data yang didapat untuk menggambarkan respon siswa, orang tua dan guru serta kesulitan yang didapat pada pelajaran PAI selama pembelajaran daring.

Penelitian ini dilaksanakan di SMP Qur'an Darul Fattah Bandar Lampung pada semester genap Tahun Pelajaran 2020/2021 untuk mata pelajaran PAI siswa kelas VIII dengan jumlah 36 siswa yang beralamat di jalan kopi 23 A Gedung Meneng, Raja basa.

Untuk mendapatkan data yang dibutuhkan, maka peneliti melakukan beberapa teknik pengumpulan data dengan observasi, wawancara, kuesioner dan dokumentasi. Sedangkan Teknik analisis data yang digunakan dalam penelitian yaitu dengan mereduksi data, penyajian data dan yang terakhir dengan verifikasi data (Miles and Huberman 2014:18).

\section{HASIL DAN PEMBAHASAN}

\section{HASIL}

\section{Deskripsi Analisis Wawancara Guru PAI SMP Qur'an Darul Fattah Bandar}

\section{Lampung}

Berdasarkan hasil wawancara peneliti dengan guru PAI pada hari Kamis 24 Agustus 2020 melalui aplikasi WhatApps dengan kisi-kisi pertanyaan: jumlah siswa kelas VIII SMP Qur'an Darul Fattah Bandar Lampung, dampak covid-19 terhadap proses belajar siswa, keefektifan belajar daring dalam tujuan pembelajaran, tanggapan mengenai proses belajar PAI dalam jaringan, kesulitan yang ditemui pada pembelajaran daring, media pendukung pembelajaran daring, metode pembelajaran, penilaian terhadap siswa, memantau siswa, dan saran terhadap pemerintah. Ibu Siti Nur Aini selaku guru PAI mengatakan bahwa “ 
dampak Covid terhadap proses belajar siswa lumayan besar, karena dengan adanya wabah ini semua proses pembelajaran berubah dari tatap muka menjadi daring yang sebelumnya belum pernah di terapkan di dalam pembelajaran SMP Qur'an Darul Fattah Bandar Lampung, sehingga proses belajar mengajar kurang efektif. Media yang digunakan selama daring adalah WhatApps khusus nya melalui berbagi pesan untuk menyampaikan atau mengumpulkan tugas-tugas yang telah di bagian. Begitu pula dengan metode yang digunakan tidak bisa bervariasi karena terbatasnya aplikasi pembelajaran yang bisa digunakan selama daring. Penilaian siswa diambil dari seberapa rajin siswa hadir atau mengumpul tugas dan nilai Ulangan Semester. Sebagian besar guru berharap semoga pemerintah dapat menemukan solusi belajar yang lebih efektif dan efisien selama pandemi. Karena dengan pembelajaran daring khususnya pelajaran PAI anak cenderung kurang dapat mengerti pelajaran yang disampaikan dan anak sulit untuk menyampaikan langsung apa yang tidak ia mengerti tersebut,sehingga pembelajaran melalui daring kurang efektif diterapkan dalam pelajaran PAI".

\section{Deskripsi Analisis Respon Orang Tua}

Untuk menganalisis tanggapan atau respon orang tua, peneliti melakukan pembagian angket sebanyak 1 kali, yaitu pada tanggal 24 Agustus 2020. Pembagian angket ini dilakukan melalui Google Form, adapun hasilnya sebagai berikut:

\section{Tabel 1}

Hasil Angket Orang Tua

\begin{tabular}{|c|c|c|c|c|}
\hline \multirow{2}{*}{ No } & \multicolumn{3}{|c|}{ Jawaban } & \multirow{2}{*}{ Jumlah } \\
\cline { 2 - 4 } & A & B & C & \\
\hline 1 & $4(11,1 \%)$ & $11(30,6 \%)$ & $21(58,3 \%)$ & $36(100 \%)$ \\
\hline 2 & $30(83,3 \%)$ & $3(8,3 \%)$ & $3(8,3 \%)$ & $36(100 \%)$ \\
\hline 3 & $6(16,7 \%)$ & $15(41,7 \%)$ & $15(41,7 \%)$ & $36(100 \%)$ \\
\hline 4 & $12(33,3 \%)$ & $15(41,7 \%)$ & $9(25 \%)$ & $36(100 \%)$ \\
\hline 5 & $11(30,6 \%)$ & $16(44,4 \%)$ & $9(25 \%)$ & $36(100 \%)$ \\
\hline 6 & $9(25 \%)$ & - & $27(75 \%)$ & $36(100 \%)$ \\
\hline
\end{tabular}




\begin{tabular}{|c|c|c|c|c|}
7 & $20(55,6 \%)$ & $10(27,8 \%)$ & $6(16,7 \%)$ & $36(100 \%)$ \\
\hline 8 & $27(75 \%)$ & $4(11,1 \%)$ & $5(13,9 \%)$ & $36(100 \%)$ \\
\hline 9 & $18(50 \%)$ & $12(33,3 \%)$ & $6(16,7 \%)$ & $36(100 \%)$ \\
\hline 10 & $8(22,2 \%)$ & $10(27,8 \%)$ & $18(50 \%)$ & $36(100 \%)$ \\
\hline
\end{tabular}

Dari angket respon Orang Tua di atas dapat peneliti simpulkan bahwa:

1) Sebanyak $11,1 \%$ orang tua yang setuju dengan pembelajaran daring dan yang tidak setuju dengan pembelajaran daring adalah 58,3\%. Sedangkan yang biasa saja dengan adanya pembelajaran daring 30,6\%.

2) Respon orang tua siswa yang khawatir terhadap penularan virus di sekolah cukup tinggi dilihat persentasenya yang mencapai $83,3 \%$ dan sisanya seimbang antara biasa saja dengan yang tidak khawatir yaitu $8,3 \%$.

3) Dalam hal mendampingi siswa selama pembelajaran daring, yang tidak siap dengan yang biasa saja memiliki persentase yang sama yaitu $41,7 \%$ yang artinya terdapat masing-masing 15 responden yang memilih jawaban tersebut sedangkan $16,7 \%$ atau 6 responden siap mendampingi siswa selama pembelajaran daring.

4) 12 orang tua atau 33,3\% setuju bahwa pembelajaran daring memberikan ketenangan kepada mereka, 15 orang tua atau 41,7 merasa biasa saja dengan adanya pembelajaran daring dan $25 \%$ orang tua atau 9 responden tidak setuju dengan pernyataan bahwa pembelajaran daring memberikan ketenangan kepada mereka.

5) $30,6 \%$ orang tua merasa fasilitas di rumah dapat menunjang pembelajaran daring dan $25 \%$ orang tua merasa fasilitas di rumah tidak dapat menunjang pembelajaran daring. Sedangkan orang tua yang merasa fasilitas mereka biasa saja atau dalam kata lain terkadang dapat menunjang dan kadang tidak berjumlah $25 \%$.

6) Orang tua yang merasa pembelajaran daring efektif dilakukan selama covid-19 berjumlah 9 orang yang apabila di persentasekan sebesar $25 \%$ dan yang tidak setuju dengan pendapat tersebut apabila dipersentasekan sebesar 75\% atau sebanyak 27 orang. 
7) Sebanyak $55,6 \%$ orang tua sepakat bahwa pembelajaran daring mengganggu rutinitas orang tua di rumah sedangkan 27,8\% menganggap tidak berpengaruh atau biasa saja dan 16,7\% menganggap pembelajaran daring tidak mengganggu rutinitas orang tua di rumah.

8) $75 \%$ orang tua setuju apabila anak mereka tetap berada di dalam pesantren selama covid-19 tentu nya dengan menerapkan protokol kesehatan yang telah ditentukan, sedangkan yang berpendapat biasa saja $11,1 \%$ dan yang tidak setuju dengan hal tersebut sebesar 13,9\%.

9) $50 \%$ orang tua kesulitan memantau Pendidikan anak di rumah dan $16,7 \%$ orang tua merasa tidak kesulitan memantau Pendidikan anak selama di rumah sedangkan 33,3\% orangtua menganggap hal tersebut biasa saja.

10) Tanggapan orang tua terhadap pembelajaran PAI yang dilakukan secara daring yaitu $22,2 \%$ merasa puas, 27,8 biasa saja dan yang tidak puas sebesar $50 \%$.

\section{Deskripsi Analisis Respon Siswa}

Untuk mendapatkan respon siswa terhadap pembelajaran daring, peneliti membagikan angket kepada siswa sebanyak 1 kali yang dilakukan melalui Google Form pada tanggal 24 Agustus 2020 dengan jumlah 36 responden.

Tabel 2

Hasil Angket Siswa

\begin{tabular}{|c|c|c|c|c|}
\hline \multirow{2}{*}{ No } & \multicolumn{3}{|c|}{ Jawaban } & \multirow{2}{*}{ Jumlah } \\
\cline { 2 - 4 } & A & B & C & \\
\hline 1 & $19(52,8 \%)$ & $17(47,2 \%)$ & - & $36(100 \%)$ \\
\hline 2 & $10(27,8 \%)$ & $25(69,4 \%)$ & $1(2,8 \%)$ & $36(100 \%)$ \\
\hline 3 & $11(30,6 \%)$ & $15(41,7 \%)$ & $10(27,8 \%)$ & $36(100 \%)$ \\
\hline 4 & $5(13,9 \%)$ & $11(30,6 \%)$ & $20(55,6 \%)$ & $36(100 \%)$ \\
\hline 5 & $10(27,8 \%)$ & $1(2,8 \%)$ & $25(69,4 \%)$ & $36(100 \%)$ \\
\hline 6 & $6(16,7 \%)$ & $13(36,1 \%)$ & $17(47,2 \%)$ & $36(100 \%)$ \\
\hline 7 & $10(27,8 \%)$ & $2(5,6 \%)$ & $24(66,7 \%)$ & $36(100 \%)$ \\
\hline 8 & $29(80,6 \%)$ & $7(19,4 \%)$ & - & $36(100 \%)$ \\
\hline
\end{tabular}




\begin{tabular}{|c|c|c|c|c|}
9 & $36(100 \%)$ & - & - & $36(100 \%)$ \\
\hline 10 & $36(100 \%)$ & - & - & $36(100 \%)$ \\
\hline
\end{tabular}

Dari angket respon siswa diatas dapat peneliti simpulkan bahwa:

1) Terdapat $52,8 \%$ siswa menyukai pelajaran PAI dan $47,2 \%$ siswa biasa saja dengan pelajaran PAI.

2) Siswa yang siap dengan pembelajaran daring sebesar $27,8 \%$ dan $69,4 \%$ biasa saja sedangkan $2,8 \%$ tidak siap dalam pembelajaran daring.

3) Siswa yang menyukai metode yang digunakan guru dalam pembelajaran PAI daring sebesar $30,6 \%$ dan $41,7 \%$ siswa biasa saja sedangkan $27,8 \%$ tidak menyukai metode tersebut.

4) Setengah dari siswa tidak menyukai perubahan pembelajaran yang menjadi daring, hal ini dapat dilihat dari persentase siswa yang menjawab tidak sebesar 55,6\%, dan $30,6 \%$ menjawab biasa saja sedangkan $13,9 \%$ menyukai perubahan yang terjadi.

5) Menurut 10 siswa atau 27,8\% siswa pembelajaran PAI lebih efektif dengan pembelajaran daring dan 2,8\% siswa menganggap pembelajaran daring sama saja dengan pembelajaran tatap muka sedangkan 69,4\% menganggap pembelajaran daring tidak efektif apabila dibandingkan dengan pembelajaran secara tatap muka.

6) Siswa yang tidak puas dengan pembelajaran daring khususnya PAI berkisar $41,7 \%$ dan yang merasa biasa saja sebanyak $36,1 \%$ sedangkan siswa yang merasa puas dengan pembelajaran daring sejumlah $16,7 \%$.

7) Pemberian tugas melalui daring mudah dipahami diakui oleh 10 siswa atau $27,8 \%$ sedangkan $66,7 \%$ atau 24 orang tidak setuju dan 5,6\% siswa merasa pemberian tugas melalui daring dan langsung sama saja.

8) Sebagian besar siswa telah paham akan bahaya nya covid-19, ini di tunjukkan dengan siswa yang menjawab ya sebanyak 29 orang atau $80,6 \%$ atau 29 orang.

9) $100 \%$ siswa sepakat aplikasi yang mereka gunakan selama daring PAI adalah Whatsaap.

10) $100 \%$ siswa juga sepakat bahwa fasilitas yang diberikan sekolah kepada mereka untuk mendukung pembelajaran daring adalah meminjamkan buku.

\section{Kesulitan yang dihadapi selama pelaksanaan pembelajaran PAI}


Kesulitan yang dihadapi guru yaitu Masih belum meratanya sinyal di berbagai wilayah mengakibatkan terbengkalainya proses pembelajaran daring, pembelajaran daring memiliki kesulitan dalam mengontrol siswa, dan guru kesulitan dalam memberikan penilaian terhadap siswa.

Sedangkan kesulitan yang dihadapi orang tua adalah Tidak beda jauh dengan kesulitan yang dihadapi oleh pendidik di sekolah, begitu pula yang dirasakan oleh pendidik yang berada di rumah, mereka juga merasakan kesulitan jaringan internet yang kurang memadai. Jadwal pembelajaran anak yang bertabrakan dengan rutinitas seharihari sehingga kurangnya waktu dalam pembagian kedua permasalahan tersebut. Materi anak yang sulit membuat orang tua harus lebih berfikir saat mendampingi pembelajaran anak. Dan yang terakhir adalah anak yang sulit diatur membuat orang tua harus selalu mengingatkan kewajiban anak dalam proses pembelajaran.

Adapun kesulitan yang dihadapi oleh siswa yaitu jaringan internet yang kurang memadai, dengan pembelajaran daring siswa menjadi kurang konsentrasi sehingga mengakibatkan kesulitan dalam memahami pelajaran, tidak memiliki perangkat digital, dan tidak dapat bertanya langsung dengan guru.

\section{PEMBAHASAN}

Berdasarkan perolehan data yang telah peneliti kumpulkan melalui Wawancara, Angket dan dokumentasi bahwa proses kegiatan pembelajaran dalam jaringan pada pelajaran PAI di SMP Qur'an Darul Fattah Bandar Lampung terbilang kurang efektif karena beberapa kendala.

Tabel 4

\begin{tabular}{|c|c|c|c|}
\hline & \\
\hline Pembahasan & Guru & Orang Tua & Siswa \\
\hline $\begin{array}{l}\text { Tanggapan } \\
\text { responden } \\
\text { terhadap } \\
\text { keefektifan } \\
\text { pembelajaran } \\
\text { daring }\end{array}$ & $\begin{array}{l}\text { pembelajaran } \\
\text { daring khususnya } \\
\text { pelajaran PAI, } \\
\text { anak cenderung } \\
\text { kurang dapat } \\
\text { mengerti pelajaran } \\
\text { yang disampaikan } \\
\text { dan anak sulit }\end{array}$ & $\begin{array}{l}75 \% \text { orang tua } \\
\text { setuju bahwa } \\
\text { pembelajaran } \\
\text { daring tidak } \\
\text { efektif diterapkan } \\
\text { dalam } \\
\text { pembelajaran dan } \\
50 \% \text { orang tua }\end{array}$ & $\begin{array}{ll}\text { Terdapat } & 69 \% \\
\text { siswa yang } & \\
\text { menganggap } & \\
\text { pembelajaran } & \\
\text { secara tatap muka } & \\
\text { lebih efektif dari } \\
\text { pembelajaran } \\
\text { daring dan }\end{array}$ \\
\hline
\end{tabular}




\begin{tabular}{|c|c|c|c|}
\hline & $\begin{array}{l}\text { untuk } \\
\text { menyampaikan } \\
\text { langsung apa yang } \\
\text { tidak ia mengerti } \\
\text { tersebut, sehigga } \\
\text { pembelajaran ini } \\
\text { kurang efektif } \\
\text { apabila di } \\
\text { terapkan dalam } \\
\text { pembelajaran PAI }\end{array}$ & $\begin{array}{l}\text { tidak puas dengan } \\
\text { pembelajaran } \\
\text { melalui daring }\end{array}$ & $\begin{array}{l}\text { berkisar sekitar } \\
50 \% \text { ke atas yang } \\
\text { tidak menyukai } \\
\text { perubahan pada } \\
\text { pelaksanaan } \\
\text { pembelajaran }\end{array}$ \\
\hline $\begin{array}{l}\text { Kesulitan yang di } \\
\text { dapat selama } \\
\text { pelaksanaan } \\
\text { pembelajaran } \\
\text { daring }\end{array}$ & $\begin{array}{l}\text {-Jaringan internet } \\
\text { yang kurang } \\
\text { memadai } \\
\text {-Kesulitan dalam } \\
\text { pengontrolan } \\
\text { siswa } \\
\text {-Kesulitan dalam } \\
\text { memberi penilaian }\end{array}$ & $\begin{array}{l}\text {-Jaringan internet } \\
\text { yang kurang } \\
\text { memadai } \\
\text {-Kurangnya waktu } \\
\text {-Materi anak yang } \\
\text { susah } \\
\text {-Anak yang sulit } \\
\text { diatur }\end{array}$ & $\begin{array}{l}\text {-Jaringan internet } \\
\text { yang kurang } \\
\text { memadai } \\
\text {-Kurang } \\
\text { konsentrasi } \\
\text {-Kesulitan } \\
\text { memahami } \\
\text { pelajaran } \\
\text {-Tidak ada yang } \\
\text { mendampingi } \\
\text { belajar di rumah } \\
\text {-Tidak memiliki } \\
\text { perangkat digital } \\
\text {-Tidak dapat } \\
\text { bertanya langsung } \\
\text { dengan guru }\end{array}$ \\
\hline
\end{tabular}

Dari tabel di atas dapat diketahui bahwa:

1) Ketiga responden memiliki respon yang sinkron atau setuju bahwasannya pembelajaran PAI yang dilakukan secara daring kurang efektif.

2) Sulitnya menumbuhkan semangat siswa dalam pembelajaran daring karena dianggap membosankan.

3) Kesulitan juga yang dialami ketiga responden adalah jaringan internet yang kurang memadai. 
4) Kurangnya waktu yang dimiliki orang tua menjadikan anak tidak ada yang mendampingi saat pembelajaran daring.

5) Siswa yang tidak memiliki perangkat digital dapat menghambat rutinitas yang dimiliki orang tua dan guru.

\section{KESIMPULAN}

Berdasarkan hasil penelitian, dapat disimpulkan bahwa pembelajaran daring kurang efektif jika diterapkan dalam pembelajaran terlebih mata pelajaran PAI. Hal ini terlihat jelas berdasarkan data yang didapatkan peneliti dari guru, orang tua dan siswa. Waktu pembelajaran daring yang banyak dilakukan siswa di rumah menjadikan orang tua lebih aktif dalam membimbing anaknya, akan tetapi tidak semua orang tua dapat mendampingi anakanaknya dalam pembelajaran terlebih mereka yang berkerja. Dan ada juga siswa yang tidak memiliki perangkat digital sehingga sulit melaksanakan pembelajaran daring, terlebih harus didukung oleh kuota yang memadai.

\section{DAFTAR PUSTAKA}

Albert Efendi. 2020. Konsep Pembelajaran Daring Berbasis Pendekatan Ilmiah. Jawa Tengah: CV. Sarnu Untung.

Asna Andriani. 2015. Urgensi Pembelajaran PAI Dalam Pendidikan Islam. Ta'allum. 3 (1).

Diakses di http://ejournal.iaintulungagung.ac.id/index.php/taalum/article/viewFile/335/269 [tanggal 7 Agustus 2020]

Keputusan Menteri Kesehatan Republik Indonesia Nomor HK.01.07/MENKES/382/2020

Menteri Pendidikan dan Kebudayaan Republik Indonesia mengeluarkan Surat Edaran

Nomor 4 tahun 2020 Tentang Pelaksanaan Kebijakan Pendidikan Dalam Masa Darurat Penyebaran Covid

Miles and Hubermen. 2014. Analisis Data Kualitatif. Jakarta: UI Press 
Napsawati. 2020. Analisis Situasi Pembelajaran Ipa Fisika dengan Metode Daring di Tengah Wabah Covid-19. Karst: Jurnal Pendidikan Fisika dan Terapannya. 1 (3). Di akses di http://ejournals.umma.ac.id/index.php/karts/article/view/546 [tanggal 20 Agustus 2020]

Rini Mastuti,dkk.. 2020. Teaching From Home:dari Belajar Merdeka Menuju Merdeka Belajar: Yayasan Kita Menulis.

Sugiyono. 2017. Metode Penelitian Kuantitatif, Kualitatif, dan R\&D. Bandung:

Alfabeta.

Suharsimi Arikunto. 2012. Dasar-Dasar Evaluasi Pendidikan. Jakarta: Bumi

Aksara.

Sutrisno Djaja. 2017. Harapan dan Tantangan Guru Pembelajar Moda Daring. Jurnal

Pendidikan Ekonomi: jurnal ilmu ilmiah pendidikan, ilmu ekonomi dan ilmu sosial. 10 (2). Di akses di

https://www.google.com/search?q=harapan+dan+tantangan+guru+pembelajar+moda + daring\&oq=harapan+dan+tantangan+guru+pembelajar+moda+daring\&aqs=chrome. .69i57j015.20332j0j7\&sourceid=chrome\&ie=UTF-8 [tanggal 17 Agustus 2020]

Ulin Nuha. 2016. Ragam Metodologi \& Media Pembelajaran PAI.

Yogyakarta: Diva Press. 